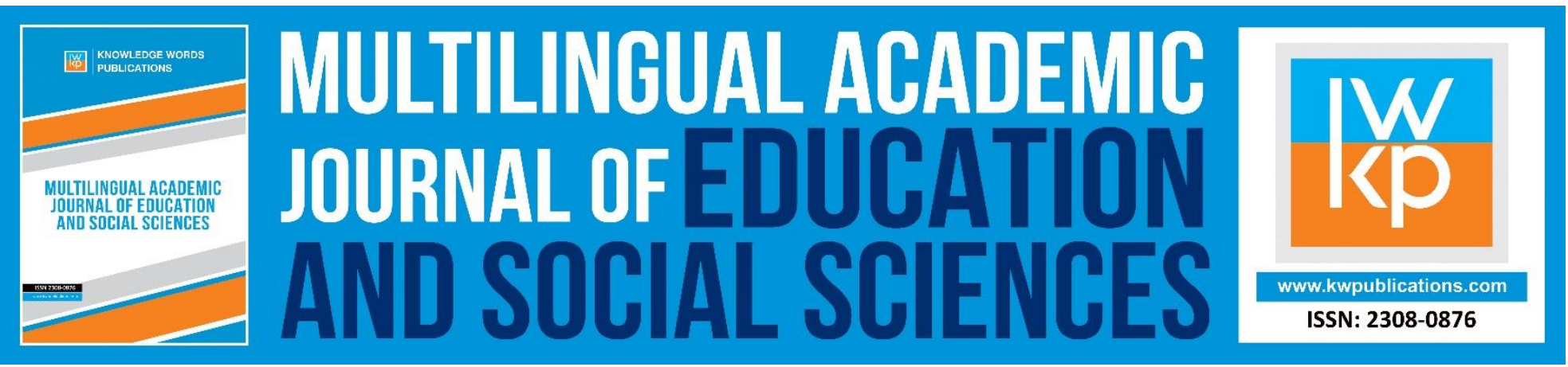

\title{
Promoting Students' Critical Literacy through the Use of Popular Culture Texts in the Formal Language Classroom
}

\author{
Polyxeni Manoli
}

To Link this Article: http://dx.doi.org/10.46886/MAJESS/v7-i1/5938

DOI: $10.46886 / \mathrm{MAJESS} / \mathrm{v} 7-\mathrm{i} 1 / 5938$

Received: 15 June 2019, Revised: 12 August 2019, Accepted: 26 August 2019

Published Online: 22 September 2019

In-Text Citation: (Manoli, 2019)

To Cite this Article: Manoli, P. (2019). Promoting students' critical literacy through the use of popular culture texts in the formal language classroom. Multilingual Academic Journal of Education and Social Sciences, 7(1), 47-56.

\section{Copyright: (c) The Authors 2019}

Published by Knowledge Words Publications (www.kwpublications.com)

This article is published under the Creative Commons Attribution (CC BY 4.0) license. Anyone may reproduce, distribute, translate and create derivative works of this article (for both commercial and non-commercial purposes), subject to full attribution to the original publication and authors. The full terms of this license may be seen at: http://creativecommons.org/licences/by/4.0/legalcode

Vol. 7, No. 1, 2019, Pg. 47 - 56

Full Terms \& Conditions of access and use can be found at https://kwpublications.com/pages/detail/publication-ethics 


\title{
Promoting Students' Critical Literacy Through the use of Popular Culture Texts in the Formal Language Classroom
}

\author{
Polyxeni Manoli \\ MA Programme 'Language Education for Refugees and Migrants', School of Humanities, \\ Hellenic Open University, Patras
}

\begin{abstract}
This study points out the need to integrate popular culture texts into formal language teaching and suggests some pedagogical applications based on various research findings. In particular, it discusses that the inauguration of the digital era, the important role that the mass media play in our contemporary lives, the emphasis on new kinds of literacies, Multiliteracies, attributing importance to the various semiotic modes of meaning making, have contributed to the emergence of texts, such as comics, texts coming from magazines, newspaper, television movies and series, advertisements, posters, and social media; these kinds of texts constitute an integral part of students' lives and tend to recycle the prevalent social ideologies. Allowing for the dynamic, semiotic and constantly changing social context, it is held that the school should develop students' critical literacy in terms of the dominant sociolinguistic representations that are constructed in the popular culture texts, acknowledging, though, that the implementation of critical literacy programmes at school is a complex and multidimensional process requiring the cultivation of an open and exploratory learning environment, teachers' and parents' education. Keywords: Critical Literacy, Popular Culture Texts, Language Teaching Practices.
\end{abstract}

\section{Introduction}

The emphasis on the communicative approach to the language teaching has accentuated the need to associate formal teaching practices with students' social life in an attempt to bridge the gap between students' everyday informal speech and the formal one used in the classroom. This demand became more evident by the approaches put forward by the New Literacy Studies (e.g., Gee, 2004; Street, 1993) focusing on the literacies that students use in their daily life and formulating the Home-School Mismatch Hypothesis (Luke, 2004).

In particular, the researchers of the New Literacies Studies attempted to understand how student use literacies in their daily lives, which are not usually promoted in the school context. They alleged that students' everyday literacy practices are often rich, complicated and equal to those boosted in the school context, as they consist of different kinds of texts that combine a 
MULTILINGUAL ACADEMIC JOURNAL OF EDUCATION AND SOCIAL SCIENCES

Vol. 7 No. 1, 2019, E-ISSN: 2308-0876 @ 2019 KWP

complex interplay of the various semiotic modes, such as the linguistic, the visual, the audio or spatial modes (Kress, Jewitt, Ogborn and Tsatsarelis, 2001; Kress and Van Leeuwen, 2006). The inauguration of the digital era, the important role that the mass media play in our contemporary lives, the emphasis on new kinds of literacies, Multiliteracies, attributing importance to other modes of meaning making, such as the visual, the audio or spatial, have contributed to the emergence of texts, such as comics, texts coming from magazines, newspaper, television movies and series, advertisements, posters, and social media (Cope and Kalantzis, 2000; Kress et al. 2001); these kinds of texts are known as popular culture texts and tend to recycle the prevalent social ideologies (Fiske, 2010; Storey, 2006). In this way, students should become familiar with new text practicesin terms of how to understand and produce meaning, as meaning-making in contemporary texts is an increasingly multimodal process (Cope and Kalantzis, 2000; Kress et al. 2001).Therefore, in this dynamic, semiotic and constantly changing social context, the school should develop students' communicative and critical skills through a variety of text genres and communicative circumstances (Tsami, Fterniati and Archakis, 2016).

\section{The Importance of using Popular Culture in the Classroom}

The New Literacy Studies focusing on the literacy practices that students use in their daily lives beyond the school context demonstrated their complex nature and highlighted the need to integrate them into the formal classroom, as it is not the students that should adapt to the school needs but it is the school that should recognize and incorporate them in the Curricula. After all, the popular culture has already been integrated into many Curricula on an international level, as it plays a prominent role in students' daily literacy practices (e.g., Alvermann, Moon and Hagood, 1999; Morrell, 2002; Stevens, 2001). The popular culture is also considered to be an association between teacher script and student script (Guitiérrez, Baquedano- Lopez and Tejeda, 2000). Moreover, according to research using the popular culture into classroom helps students be more actively engaged in the learning process and boosts their creativity (Duff, 2004). At the same time, it has been shown that the use of popular culture in the school context helps students develop early literacy skills, such as identifying letters and words, and narration skills (e.g., Linebarger and Piotrowski, 2009).

In addition, the major contribution of the use of popular culture in the school context is that it associates the literacies students use in their social life with the teaching practicesused at school, which is important, especially for students coming from less privileged families. In particular, research has indicated that students stemming from a lower socio-economic and educational background are more familiar with these literacies, such as the popular culture, than those that come from more privileged families and are usually more familiar with the formal literacy practices (e.g., Koutsogiannis, 2011; Livingstone and Bovill, 1999; Marsh et al. 2005; Stamou, Maroniti and Schizas, 2014; Tsami, Archakis, Fterniati, Papazachariou and Tsakona, 2014). Simultaneously, according to research conducted in the context of the research project 'Thalis', it was found that the families that belonged to a higher socio-economic and educational background had greater access to literacies that are close to those emphasized at school, such as reading books and using computers, than the families that had a lower socio-economic and educational background (Stamou et al. 2014); on the contrary, it was revealed that less privileged families had greater access to practices that were more oriented to the popular culture, such as increased use of television programmes and videogames) when compared to more privileged 
MULTILINGUAL ACADEMIC JOURNAL OF EDUCATION AND SOCIAL SCIENCES

Vol. 7 No. 1, 2019, E-ISSN: 2308-0876 @ 2019 KWP

families, which also concurred with relevant research (Fterniati, Archakis, Papazachariou and Tsami, 2013; Tsami et al., 2014).

Undoubtedly, the above research findings are indicative of the primary role that the family plays in students' school success or failure. According to Bernstein (1971), students coming from a lower social status had a restricted language code, which significantly differed from that used at school, which is more elaborated. In this way, the relevant research on the students' literacy practices beyond the school context shed light on students' socially differentiated school progress highlighting that it existed not only because of the different language code but also because of the various literacy practices that students were exposed to within the first place of their socialization, that is the family.

Taking all the above into consideration, the use of popular culture at school can be seen as a possible way to bridge the gap between the social inequalities in the field of education, as it was shown that students coming from a lower social status were more familiar with it. Despite some skepticism that has been exerted in terms of whether the use of popular culture at school could be an obstacle for migrant students, as they may not have been familiar with it because of their different socio-cultural background (Duff, 2004), research conducted in Greece has indicated that migrant students did not differ in their television and music preferences from their native peers (Griva and Stamou, 2014; Fterniati et al. 2013; Tsami et al. 2014); concurrently, it is worth mentioning that some migrant parents stated that watching Greek television constituted a strategy to help their children socially integrate into the Greek way of living (Griva and Stamou, 2014).

\section{Critical Literacy}

The concept of critical literacy has started to be used in a systematic way since the 1990s, though it has already been spotted in the pedagogy of Freire since the 1960s (Stamou, Archakis and Politis, 2016). Critical literacy constituted a pedagogical philosophy (Tendolouris and Chatzisavvidis 2014) in which different approaches co-existed. Curdt-Christensen(2010, as cited in Tsakona, 2014, 21) defined the term critical literacy as the ability to study, examine and understand a text posing different questions, such as: what the purpose of the text is, why it has been created, the different ways a text could be created as well asthe different functions that a text could have (Baynham 2002, as cited in Archakis and Tsakona, 2011, 202-3). According to Koutsogiannis (2014), instead of using the term critical literacy, it is preferable to use the term critical literacies, which significantly differ. In particular, critical literacies held that developing literacy through text interaction not only aims at students' effective function as future citizens in the various communicative circumstances (functional literacy) but also at developing their critical skills (Stamou et al. 2016). In this context, texts are not regarded as neutral semantic entities but ideological constructs that promote a specific perspective of the world.

Attempting to summarize the taxonomy according to which critical literacies have been applied in the teaching process, we could mention four (4) basic ones: the pedagogical, the linguistic, the sociopolitical and the ethnographic (see also Tendolouris and Chatzisavvidis, 2014). To be more specific, the pedagogical tradition has been associated with the field of Freire's, Giroux's, and McLaren's critical pedagogy according to which critical literacy is seen as a means of social awakening and empowering aiming at the transformation of society through education and emphasizing active learning and critical skills (Stamou et al. 2016). In addition, the linguistic 
MULTILINGUAL ACADEMIC JOURNAL OF EDUCATION AND SOCIAL SCIENCES

Vol. 7 No. 1, 2019, E-ISSN: 2308-0876 @ 2019 KWP

tradition, which has its roots in the Critical Linguistics (Fowler, Hodge, Kress and Trew, 1979) and Halliday's (1994) Systemic Functional Grammar, highlights the role of language in the meaningmaking process. In this context, critical literacy emphasizing critical analysis of texts is viewed as a way to help students understand the latent ideological messages of texts that they are exposed to. Critical language awareness (Fairclough, 1992; Janks, 1999), Genre-based pedagogies (Hyland 2003, 2004) as well as Multiliteracies (New London Group 1996)belong to the linguistic tradition of critical literacies. Moreover, the sociopolitical tradition has been associated with researchers, such as Luke and Freebody (1997), who developed the Four Resources Model, a teaching model of critical reading, and focused on texts regarding them as a means to depict social reality and the language used in the mass media; namely, it emphasizes the content of texts and the representations of the world that they promote rather than the language means through which the text meanings are constructed. Last but not least, the ethnographic tradition, which has its roots in Hymes ethnography of communication, views literacy as a situated social practice; it aims at understanding how literacy practices are associated with social ones and how reality is constructed through literacy practices. In this way, it focuses on the literacy practices used beyond the school content where students are asked to select texts and figure out the ways text meaning is perceived and produced (Stamou et al., 2016).

Therefore, it can be concluded that these traditions mentioned above can approach critical literacy from different ideologies and perspectives indicating various language teaching practices without regarding them as opposite versions of critical literacy (Tendolouris and Chatzisavvidis, 2014); on the contrary, they can be seen as different faces of the same coin, as each of them sheds light on different perspectives of the multi-dimensional practice of critical literacy, which cannot function independently but in combination with each other allowing for the teaching conditions (e.g., students' traits) and the broader socio-cultural context.

\section{Applying Critical Literacy in the School Context}

In terms of critical literacy implementation at school, various teaching practices have been put forward, some of which can be summarized below (Kontovroukh and Iwannidou, 2013):

- Using texts that are closely associated with students' interests and experiences deriving from their everyday lives

- Text analyses that correlate the language elements of texts with the broader social practices, identities and relationships

- Acquiring reading and writing skills whileexploring social issues

- Contrastive analysis of various texts with the aim of comparing and contrasting different perspectives of the world that are depicted in the texts

- Multiple readings of the same text aiming at shedding light on the reader's various interpretations of the text itself

In Greece, particularly, a lot of research has been conducted in the context of the research project 'Thalis' on the way students perceive the mass media representations of languagevariation when applied at school putting forward forward various teaching practices. Relevant studies have indicated that not only the fifth and sixth graders of primary school (e.g., Fterniati et al. 2013; Tsami et al. 2014), but also pre-school students (Stamou, Maroniti and Griva, 2015) and first graders (Stamou et al. 2015) were aware of the language variation, as they were able to distinguish between language variations that the differentfictional characters used, 
MULTILINGUAL ACADEMIC JOURNAL OF EDUCATION AND SOCIAL SCIENCES

Vol. 7 No. 1, 2019, E-ISSN: 2308-0876 @ 2019 KWP

without having developed their critical literacy, as they tended to readily accept the various messages promoted by the producers of the popular-culture texts.

More specifically, Maronith, Stamou, Griva and Dinas (2016) implemented a program of critical literacy to first and second graders of primary school aiming at developing students' critical awareness of language variation in terms of geographical and social dialects identified in television fictional texts, such as advertisements, cartoons, and television series. The results of the study indicated that students' sociolinguistics awareness was improved, as they were able to perceive that the language variation which the fictional characters used often created misunderstandings and that there was a considerable divergence between the fictional characters' speech watched on TV and their sociolinguistic experience; however, some difficulties were noticed, when students were asked to critically transfer the newly-acquired knowledge to

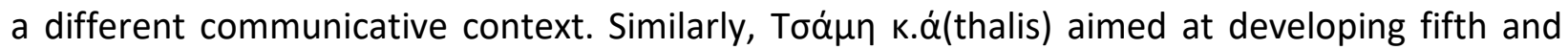
sixth graders' critical literacy through the use of popular-culture texts, such as television advertisements and comic series, representing language variations based on region and teaching practices emphasizing the role of humor in the critical teaching of language variation.

Simultaneously, Kefalidou's study (2016) reconsidered the teaching of narration, as it is delineated in the current curriculum of the language and the pertinent teaching materials in the secondary education, exerting criticism on the dominance of the narration in literature and suggested the teaching of narration, as it is used in the mass media, which views narration as a means of constructing identifies and ideologies. Namely, it studies the use of narration, as it is used in the television news, including news coming from the police bulletin, natural disasters etc and taking advantage of the visual semiotic mode (e.g., videos, photos, graphs), which indicates that the meaning making process in the narration can be the outcome of the interplay of various semiotic modes. In addition, Douka, Fterniati and Archakis (2016) proposed teaching practices for the language classroom in the high school, as they analysed the speech used in the mass media, particularly in articles coming from newspapers, aiming at showing the ideologies that permeate reporters' language options in these kinds of texts as well as rendering students critically literate in terms of perceiving the ideologies that lie behind the news released in the mass media. Moreover, Lee (2016)studied the type of language deployed by secondary school students on facebook, the most popular means of social media, to identify the divergence between children's everyday language use and that used in the school classroom and proposed teaching practices that would make students highly aware of the language variation of modern communication as occurred in social media; it was found that the language deployed on facebook was a combination of both the oral and written speech, which, for example, included an excessive use of diminutive adjectives to help students denote feelings, such as tenderness, affection, approval, as well as a positive predisposition that constitutes a prerequisite for the smooth communication among teenager peers. Vazou (2016) also focused on the use of internet sites of tourist organizations as a way to promote multiliteracies in the secondary education, which attempt to promote tourism through a promotional language use and the visual mode; in this context, the integration of such a site into the language classroom can boost the studying of 
MULTILINGUAL ACADEMIC JOURNAL OF EDUCATION AND SOCIAL SCIENCES

Vol. 7 No. 1, 2019, E-ISSN: 2308-0876 @ 2019 KWP

multimodal types of speech used on the internet, the organization, the ideology and the appropriate strategies that lie behind it to attract Greek and foreign visitors.

\section{Concluding Remarks}

Overall, the above research findings highlight the need for the development of students' critical literacy in terms of the dominant sociolinguistic representations that are constructed in the popular culture texts. However, there is no doubt that the implementation of critical literacy programmes at school is a complex and multidimensional process, as it presupposes the cultivation of an open and exploratory learning environment, teachers' (Chairistanidhs, 2014; Kontovroukh and Iwannidou, 2013; Marwnith and Stamou, 2014) and parents' education (Stamou et al. 2014) in terms of critical literacy and the use of popular culture texts in the classroom to support similar teaching practices.

\section{References}

Alvermann, D., Moon, J., \& Hagood, M. (1999). Popular culture in the classroom. Newark, DE \& Chicago: International Reading Association and the National Reading Conference.

Archakis, A., \& Tsakwna, V. (2011). Taytothtes, afhghseis kai glwssikh ekpaideysh [Identities, narrations and language education]. Athina: Patakis.

Bernstein, B. (1971). Class, codes and control: Theoretical studies towards a sociology of language. London: Routledge \& Kegan Paul.

Chairistanidhs, L. (2014). Chartographhsh twn apopsewn twn ekpaideytikwn ths prwtovatmias ekpaideyshs gia themata (kritikou) grammatismou [Mappring primary teachers' views on critical literacy issues]. Adhmosieyth Metaptyxiakh Diplwmatikh Ergasia. Flwrina: PanepisthmioDytikhsMakedonias.

Cope, B., \& Kalantzis, M. (2000). Introduction: Multiliteracies: The beginnings of an idea. In B. Cope \& M. Kalantzis (Eds.), Multiliteracies: Literacy learning and the design of social futures (pp. 3-8). London and New York: Routledge.

Douka, A., Fterniati, A., Archakis, A. (2016). Eidhseografikos logos kai kritikh glwssikh ekpaideysh sto plaisio twn polygrammatismwn: Didaktikes protaseis gia to glwssiko mathhma ths B' Lykeiou [News speech and critical language education in the context of multiliteracies: Teaching proposals for the language classroom at the second grade of High School]. In A.G. Stamou, P. Poliths, and A. Archakis, Glwssikh poikilothta kai kritikoi grammatismoi ston logo ths mazikhs koultouras: Ekpaideytikes protaseis gia to glwssiko mathhma (pp. 140-175). Kavala: Saita.

Duff, P. A. (2004). Intertextuality and hybrid discourses: The infusion of pop culture in educational discourse. Linguistics \& Education, 14, 231-276.

Fairclough, N. (1992). Critical language awareness. London \& New York: Longman.

Fiske, J. (2010). Understanding popular culture. London: Routledge.

Fowler, R., Hodge, R., Kress, G., \& Trew, T. (1979). Language and control. London: Routledge \& Kegan Paul.

Fterniati, A., Archakis, A., Papazachariou, D., \& Tsami, V. (2013). Anixneysh twn protimhsewn mathhtwn/triwn E' kai ST' Dhmotikou se keimena mazikhs koultouras kai to isxyon 
MULTILINGUAL ACADEMIC JOURNAL OF EDUCATION AND SOCIAL SCIENCES

Vol. 7 No. 1, 2019, E-ISSN: 2308-0876 @ 2019 KWP

didaktiko yliko [Exploring $5^{\text {th }}$ and $6^{\text {th }}$ graders' preferences to popular culture texts and the prevalent teaching material. Nea Paideia, 145, 61-77.

Gee, J. P. (2004). Situated language and learning: A critique of traditional schooling. London: Routledge.

Griva, E., \& Stamou, A. G. (2014). Ereynwntas th diglwssia sto sxoliko perivallon: Optikes ekpaideytikwn, mathhtwn kai metanastwn gonewn [Exploring bilingualism in the school context: Teachers', students' and migrant parents' perspectives]. Thessaloniki: Kyriakides.

Gutiérrez, K., Baquedano-Lopez, P., \& Tejeda, C. (2000). Rethinking diversity: Hybridity and hybrid language practices in the third space. Mind, Culture, \& Activity: An International Journal, 6(4): 286-303.

Halliday, M. A. K. (1994). An introduction to functional grammar. London: Edward Arnold.

Hyland, K. (2003). Genre-based pedagogies: A social response to process. Journal of Second Language Writing, 12(1): 17-29.

Hyland, K. (2004). Genre and second language writing. Ann Arbor, MI: University of Michigan Press.

James, C., \& Garrett, P. (1991). Language awareness in the classroom. London: Longman. Janks, H. (1999). Critical language awareness journals and student identities. Language Awareness, 8,111-122.

Kefalidou, S. (2016). Oi afhghseis thleoptikwn eidhsewn: Mia protash gia thn analysh kai th didaskalia tous sto Gymnasio [Narrations of television news: A proposal for their analysis and teaching in secondary school]. In A.G. Stamou, P. Poliths, and A. Archakis, Glwssikh poikilothta kai kritikoi grammatismoi ston logo ths mazikhs koultouras: Ekpaideytikes protaseis gia to glwssiko mathhma (pp. 107-139). Kavala: Saita.

Kontovroukh, S., \& Iwannidou, E. (2013). Kritikos grammatismos sto kypriako sxoleio: Antilhpseis, praktikes kai staseis ekpaideytikwn [Critical literacy in the Cypriot school: Teachers' views, practices and attitudes]. Prosxolikh \& Sxolikh Ekpaideysh, 1, 82-107.

Koutsogiannis, D. (2014). Kritikoi grammatismoi: Diethnhs empeiria kai ellhnikh pragmatikothta [Critical literacies: International experience and Greek reality]. Sto E. Griva, D. Koutsogiannis, K. Dinas, A.G. Stamou, A. Chatzipanagiwtidh and S. Chatzisavvidis (Epim.), Praktika Panellhniou Synedriou:'O kritikos grammatismos sth sxolikh praxh' (http://www.nured.uowm.gr/drama/PRAKTIKA.html).

Koutsogiannis, D. (2011). Efhvikes praktikes pshfiakou grammatismou kai taytothtes [Teenager's practices of digital literacy and identities]. Thessaloniki: Kentro Ellhnikhs Glwssas.

Kress, G., Jewitt, C., Ogborn, J., \& Tsatsarelis, C. (2001). Multimodal teaching and learning: The rhetorics of the science classroom. London: Continuum.

Kress, G., \& van Leeuwen, T. (2006). Reading images: The grammar of visual design. London: Routledge.

Lee, C. (2016). Apo ton toixo tou Facebook sth sxolikh taxh: H xrhsh ypokoristikwn kai megenthyntikwn stis pshfiakes glwssikes praktikes mathhtwn/triwn gymnasiou kai protaseis gia th didaskalia tous [The use of diminutive adjectives in secondary school students' digital practices and suggestions for their teaching]. In A.G. Stamou, P. Poliths, 
MULTILINGUAL ACADEMIC JOURNAL OF EDUCATION AND SOCIAL SCIENCES

Vol. 7 No. 1, 2019, E-ISSN: 2308-0876 @ 2019 KWP

and A. Archakis, Glwssikh poikilothta kai kritikoi grammatismoi ston logo ths mazikhs koultouras: Ekpaideytikes protaseis gia to glwssiko mathhma (pp. 176-198). Kavala: Saita.

Linebarger, D. L., \& Piotrowski, J. T. (2009). TV as storyteller: How exposure to television narratives impacts at-risk preschoolers' story knowledge and narrative skills.British Journal of Developmental Psychology, 27, 47-69.

Livingstone, S., \& Bovill, M. (1999). Young people, new media: Report of the research project 'Children Young People and the Changing Media Environment'. London: London School of Economics and Political Science:

http://eprints.Ise.ac.uk/21177/1/Young_people_new_media_(LSERO).pdf

Luke, A. (2004). On the material consequences of literacy. Language \& Education, 18(4), 331-335.

Luke, A., \& Freebody, P. (1997). Shaping the social practices of reading. In S. Muspratt, A. Luke, \& P. Freebody (Eds.), Constructing critical literacies(pp. 185-226). Sydney: Allen and Unwin.

Marsh, J., Brooks, G., Hughes, J., Ritchie, L., Roberts, S., \& Wright, K. (2005). Digital beginnings: Young children's use of popular culture, media and new technologies. University of Sheffield: Literacy Research Center:

http://www.digitalbeginnings.shef.ac.uk/DigitalBeginningsReport.pdf

Maronith, K., Stamou, A. G., Griva, E., \& Dinas, K. (2016). Anaparastaseis ths glwssikhs poikilothtas ston thleoptiko logo: Efarmozontas ena programma kritikou grammatismou se paidia prwtosxoloikhs hlikias [Representations of language variations in the television speech: Applying a programme of critical literacyto first and second graders of primary school]. In A.G. Stamou, P. Poliths, and A. Archakis, Glwssikh poikilothta kai kritikoi grammatismoi ston logo ths mazikhs koultouras: Ekpaideytikes protaseis gia to glwssiko mathhma (pp. 47-79). Kavala: Saita.

Maronith, K., \& Stamou, A. G. (2014). Diereynhsh twn apopsewn twn ekpaideytikwn ths prwtovathmias ekpaideyshs gia th xrhsh twn keimenwn ths mazikhs koultouras sth glwssikh didaskalia [Investigating primary teachers' views on the use of popular culture texts in the language teaching]. Meletes gia thn Ellhnikh Glwssa, 34, 271-284.

Morrell, E. (2002). Toward a critical pedagogy of popular culture: Literacy development among urban youth. JournalofAdolescent andAdult Literacy, 46, 72-77.

New London Group. (1996). A pedagogy of multiliteracies: Designing social futures.Harvard Educational Review, 66, 60-92.

Stamou, A. G., Archakis, A., Politis, P. (2016).Glwssikh poikilothta kai kritikoi grammatismoi sto logo ths mazikhs koultouras [Language variation and critical literacies in the speech of popular culture].In A.G. Stamou, P. Poliths, and A. Archakis, Glwssikh poikilothta kai kritikoi grammatismoi ston logo ths mazikhs koultouras: Ekpaideytikes protaseis gia to glwssiko mathhma(pp. 11-46). Kavala: Saita.

Stamou, A. G., Maroniti, K., \& Griva, E. (2015). Young children talk about their popular cartoon and TV heroes' speech styles: Media reception and language attitudes. Language Awareness, 24(3), 216-232.

Stamou, A. G., Maroniti, K., \& Schizas, D. (2014). Greek young children's engagement with media in the home: Parents' and children's perspectives. Studies in Media and Communication, 2(2), 93-106. 
MULTILINGUAL ACADEMIC JOURNAL OF EDUCATION AND SOCIAL SCIENCES

Vol. 7 No. 1, 2019, E-ISSN: 2308-0876 @ 2019 KWP

Stevens, L. (2001). South Park and society: Instructional and curricular implications of popular culture in the classroom. Journal of Adolescent and Adult Literacy, 44, 548-555.

Storey, J. (2006). Cultural theory and popular culture: An introduction. Essex: Pearson.

Street, B. V. (1993). The New Literacy Studies: Guest editorial. Journal of Research in Reading, 16(2), 81-97.

Tendolouris, F., \& Chatzisavvidis, S. (2014). Logoi tou kritikou grammatismou kia h 'topothethsh' tous sth sxolikh praxh: Pros mia glwssodidaktikh anastoxastikothta. [Reasons for critical literacy and its 'pacement' in the school context: Towards a language teaching reflection. Meletes gia thn Ellhnikh Glwssa,34, 411-421.

Tsakwna, V. (2014). ' $T$ ' avga pairnw monh mou': Kritikos grammatismos, epaggelmatikes syndiallages kai eygeneia ['I take the eggs on my own': Critical literacy, professional interactions, and politeness]. Glossologia, 22, 14- 39.

Tsami, V., Archakis, A., Fterniati, A., Papazachariou, D., \& Tsakona, V. (2014). Mapping elementary school students' preferences for mass cultural literacy practices. In Lemonidis, C. (Eds.),Proceedings of the 1st International Conference: "Education across Borders"(pp. 361-371). Florina, 5-7 October 2012. University of Western Macedonia.

Tsami, V., Fterniati, A., \& Archakis, A. (2016). Mazikh koultoura, glwssikh poikilothta, kai xioumor: Didaktikes protaseis gia thn anaptyxh tou kritikou grammatismou mathhtwn/triwn E' kai ST' Dhmotikou [Popular culture, language variation and humor: Teaching practices for the development of $5^{\text {th }}$ and $6^{\text {th }}$ Graders' critical literacy. In A.G. Stamou, P. Poliths, and A. Archakis, Glwssikh poikilothta kai kritikoi grammatismoi ston logo ths mazikhs koultouras: Ekpaideytikes protaseis gia to glwssiko mathhma(pp. 80-106). Kavala: Saita.

Tsami, V., Archakis, A., Fterniati, A., Papazachariou, D., \& Tsakona, V. (2014). Mapping elementary school students' preferences for mass cultural literacy practices. In Lemonidis, C. (Ed.), Proceedings of the 1st International Conference: "Education across Borders"(pp. 361-371). Florina, 5-7 October 2012. University of Western Macedonia.

Vazou, E. (2016). Oi diadiktyakes pyles touristikwn organismwn ws pedio polygrammatismwn sth deyterovathmia ekpaideysh: $\mathrm{H}$ periptwsh tou VisitGreece [The internet sites of tourist organisations used as a means of multiliteracies in the secondary education: The case of VisitGreece. In A.G. Stamou, P. Poliths, and A. Archakis, Glwssikh poikilothta kai kritikoi grammatismoi ston logo ths mazikhs koultouras: Ekpaideytikes protaseis gia to glwssiko mathhma (pp. 199-226). Kavala: Saita. 